\title{
Breath: reciprocities without words. Music, sound and videoart as communication paths on migration processes
}

Fernando Palacios Mateos ${ }^{1}$

${ }^{1}$ Universitat Politècnica de Valencia

\begin{abstract}
Breath was created during a research stay at Social Sciences department in Roskilde University in Denmark. The challenge was to find ways to disseminate knowledge through artistic resources in a research project under migration topic.
\end{abstract}

European socio-cultural contexts nowadays are established as landscapes of diversity, platforms of social interaction where the confluence of perspectives of diverse cultures are gradually modified, giving rise to new expressive parameters of social groups. This environment allows a dialogue between different cultural musical manifestations and the approaches to the sound phenomenon that each one establishes. These cultural platforms are laboratories par excellence of the transculturation as a place where the exchange of musical identities is more easily produced. They accept (or should accept) diversity not as exoticism or threatening otherness but as a possibility of one's own identity.

Under these circumstances, music plays a definitive and fundamental role constituting a purposeful and peaceful way of interaction between different cultural groups. Furthermore, music allows the development of a dialogue in the rethinking process of the collective, related to the individual.

Breath is an approach to music in a social perspective, connecting people from different genders, generations and cultures that didn't know each other before. Together we created a communication path without words, where Breath is the guideline for the improvised music. We were all synchronized in a co-creative work. The photos and drawings that appears on the video where chosen and made by the participants afterwards, reflecting what they felt during the experience. Besides, Breath is an interactive work that invites you to participate in it with your own Breath. Through a video installation, Breath pretends to arouse our empathy towards an understanding of the other. It aims to visualize our common aspects as humans and living beings, focusing on a basic one: Breathing reciprocity.

Key words: Breathing, migration, reciprocity, co-existence, empathy 


\section{Resumen}

Breath fue creado durante una estancia de investigación en el departamento de Ciencias Sociales de la Universidad de Roskilde, en Dinamarca. El reto consistía en encontrar formas de difundir el conocimiento a través de recursos artísticos en un proyecto de investigación bajo el tema de la migración.

Los contextos socioculturales europeos se establecen hoy en día como paisajes de la diversidad, plataformas de interacción social donde la confluencia de perspectivas de diversas culturas se modifican gradualmente, dando lugar a nuevos parámetros expresivos de los grupos sociales. Este entorno permite el diálogo entre las diferentes manifestaciones culturales musicales y las aproximaciones al fenómeno sonoro que cada una establece. Estas plataformas culturales son laboratorios por excelencia de la transculturación como lugar donde se produce más fácilmente el intercambio de identidades musicales. Aceptan (o deberían aceptar) la diversidad no como exotismo o alteridad amenazante, sino como posibilidad de la propia identidad.

En estas circunstancias, la música desempeña un papel definitivo y fundamental al constituir una forma de interacción intencionada y pacífica entre diferentes grupos culturales. Además, la música permite el desarrollo de un diálogo en el proceso de replanteamiento de lo colectivo, relacionado con lo individual.

Breath es un acercamiento a la música en una perspectiva social, conectando a personas de diferentes géneros, generaciones y culturas que no se conocían antes. Juntos creamos una vía de comunicación sin palabras, en la que la respiración es la pauta de la música improvisada. Todos estábamos sincronizados en un trabajo de cocreación. Las fotos y los dibujos que aparecen en el vídeo fueron elegidos y realizados por los participantes a posteriori, reflejando lo que sintieron durante la experiencia. Además, Breath es una obra interactiva que invita a participar en ella con la propia respiración. A través de una video-instalación, Breath pretende despertar nuestra empatía hacia la comprensión del otro. Pretende visualizar nuestros aspectos comunes como humanos y seres vivos, centrándose en uno básico: la reciprocidad respiratoria.

Palabras clave: Respiración, migración, reciprocidad, coexistencia, empatía.

\section{Introduction}

In 2019 during my stay as a guest researcher at Social Sciences Department in Roskilde University in Denmark, I was involved in a research project related to Social Sciences, Emotional Interaction Design for Knowledge Sharing (EMIDEKS), findings ways to 
engage music, sound and visual art as an opportunity to convey knowledge within migration processes.

Realizing that in migration interactions differences use to play a bigger role than similarities, I wondered how can we as humans be more connected one to another, how can we recognize the otherness as an epistemological subject considering our common social aspects and behaviors. One human main common aspect is Breathing. We all Breathe, we are continuously sharing the air, and this simple fact could give us a collective platform for interaction. This is how the audio-visual installation Breath arouse, gathering people from different backgrounds in a Breathing session, with music and visuals as the common thread. Despite their high visibility in the media and political discourses as flows of people, migrants often remain voiceless. Breath mediates the voices of migrants to local residents of the host society in order to promote a better understanding of the social situation of migrants by focusing on their common humanity and shedding light on sameness, recognition, mutual awareness, conviviality and solidarity.

\section{Background}

European cultural contexts nowadays are established as landscapes of diversity (Niessen, 2000, Schneider \& Heath; 2016), platforms of social interaction where the confluence of perspectives of diverse cultures are gradually modified, giving rise to new expressive parameters of social groups. Also, European cultural contexts create a dialogue between different musical manifestations and the approaches to the sound phenomenon that each one establishes. They are laboratories par excellence of the transculturation as a place where the exchange of musical identities is more easily produced (Pelinski, 2000; Bohlman, 2011; Bogdanovic, 2016). Europe is a paradigm of cultural contexts. A cultural area with a large population in situation of migration that, since de last two decades of last century, represents a landscape of diversity.

Besides, many people in migration situation move below the radar of regulatory institutions or navigate in semi-legal frameworks (Hahonou, 2019; Bank, 2014). The resulting unpredictable situations that they are force to live faces these people with a continuous repurposing of their expectations, objectives, and their mobility (Vigh, 2018).

The imbalanced accessibility of resources has been generally one of the mains motives for people to move from one place to another. Although mobility has been part of human behavior among centuries, mobile peoples at large are still regarded by sedentary communities as abnormal and deviant (Hahonou, 2019). As well, the cultural and economic contribution that migrant people represent for the host society is usually undervalued or ignored. 
Under these circumstances, and because of its power to conveys knowledge beyond words, music, sound and video art plays a definitive and fundamental role constituting a purposeful and peaceful way of interaction between different cultural groups (Baily, 2006; Palacios, 2018). Furthermore, these tools allow the development of a dialogue in the rethinking process of the collective, related to the individual (Kiwan \&Meinhof, 2011; Robinson, 2016; Kasinitz \& Martinello, 2019).

Besides, one major problem faced by academic research today is the dissemination of knowledge beyond academic audiences. Academic knowledge seems to be produced by specialists for specialists and research findings are usually presented and explained by texts (articles, books, reviews, etc.). So, how can we reach the broader public who is not familiar with academic analyses, concepts, jargons, and modes of communication more generally? That is one of the challenges the present project intends to face, to circulate knowledge beyond academy.

Under these premises, the video Installation Breath establishes the significant and central role that music, sound and video art plays in the process of dialogical communication of migrants in European socio-cultural contexts.

\section{Methodology}

A key aspect of Breath is to take into account the emotional content and impact on knowledge. Emotional design is a field of study within interaction design that recognizes that emotions play a central role in the human ability to understand and learn about the world. Music and sounds offer forms of communication mobilizing all the senses and reaching levels of knowledge beyond words, concepts and theories. Improving the participation of under-represented voices in the shaping narratives.

Innovation-action methodology was used as the key approach. The central idea of the project was related to the identification of the audience to the subject through empathy, developing and implement a theory and process of learning-by-feeling, contributing to a better understanding of otherness and promote social communication through social recognition. Besides, the proposal appeals to the power of images. We humans perceived the world that surrounds us through our senses before processing this into knowledge. Thus, images evoke deeper elements of human consciousness that do words.

Breath was developed with the participation of people from different genders, generations and cultures that didn't know each other before. Together we created a communication path without words, where Breath was the guideline for the improvised music. We were all synchronized in a co-creative work mixed and recorded in live. 
Fernando Palacios Mateos

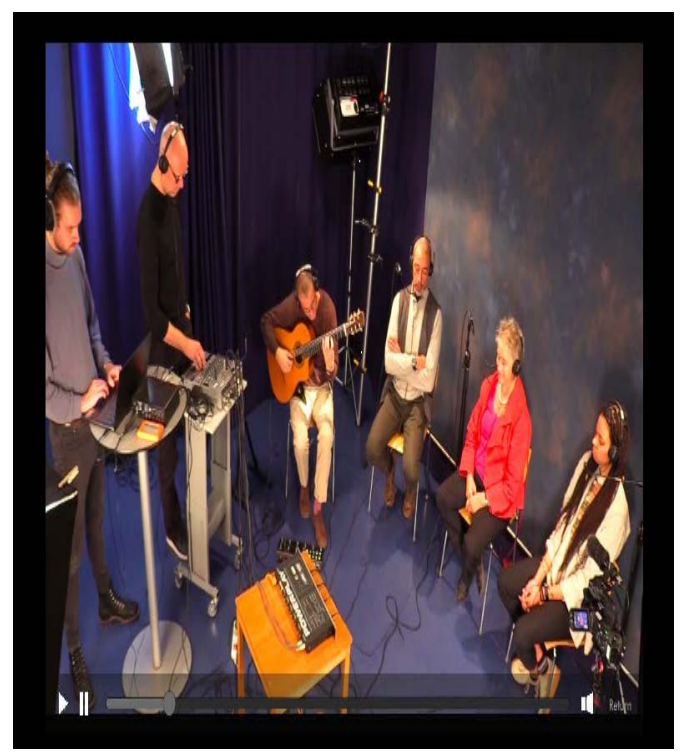

Fig. 1: Live recording session
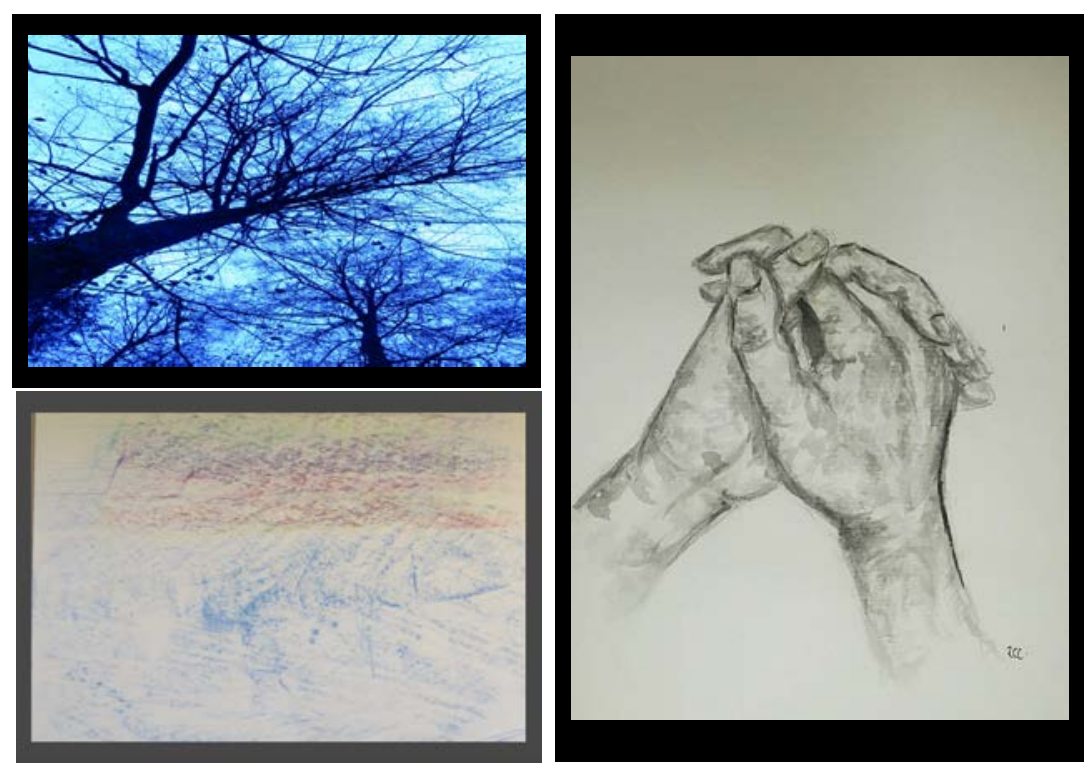

Fig. 2,3,4: Photos and drawings from the participants. 
The photos and drawings that appears on the video were chosen and made by the participants afterwards, reflecting what they felt during the experience.

Besides, Breath installation includes the interactive option to incorporate the spectators own Breathing on the video.

Sharing academic knowledge with lay audiences is a challenging problem, especially in the cultural contexts and research concerning sustainability, where results often have a direct impact on human lives and experiences. The goals of sustainability require people to absorb knowledge into their own lives and take action using the knowledge. That is the challenge that Breath intends to face, by exploring with an original methodology for experiencing knowledge through interactive videoart. Dissemination \& Outreach is committed to communicating research findings at an adequate time and level, and to a variety of audiences. As a sound installation, is committed to the use of interactive spaces to disseminate and share investigation outcomes with non-academic audiences.

The installation pretends to arouse our empathy towards an understanding of the other. It aims to visualize our common aspects as humans and living beings, focusing on a basic one: Breathing reciprocity. Breath aims to establishes a platform of interaction between different constituents of society, an accessible manner to link academia and people. A space of social transformation that can incident in an innovative and attractive manner towards the socialization of nowadays European cultural contexts through music, sound and video art by shedding light on human emotions.

\section{A transdisciplinary project}

Breath aims to contribute to a better understanding of nowadays European cultural contexts, socializing them in an accessible way through interactive physical platforms and digital tools, using music, sound and video art as the main communication channels. Enhancing a transdisciplinary research approach, it placed together different study areas as music, social sciences, information technology and audio-visuals.

The topics of migration and music are itself closely related to UN Sustainable Development Goal 10: Reduced Inequality and Goal 11: Sustainable Cities and Communities. In terms of emotional content and impact on people's lives, it also provides a representative example of knowledge related to sustainability in areas such as environment and climate. Thus, the project also relates to Goal 4: Quality Education (research-innovation action). It too establishes an accessible and interactive space of learning process; focusing on the challenge of inequalities, deepening into migration implications and realities from different perspectives; and through the lack of migration of newcomers in a variety of societies. 
Breath departs from the nuclear prefixes "trans" and "inter" involving several approaches that improves the socialization of European cultural contexts: transcultural, intergenerational and transnational; so the participants have different cultural backgrounds, ages and origins. Transdisciplinary; so people from diverse scientific areas area involved: music, sound art creation, ethnomusicology, social sciences, cultural studies, anthropology, information technology and audio-visuals. Interactive as it aims the use of interactive platforms and tools to provide multi-sensory sharing of research findings.

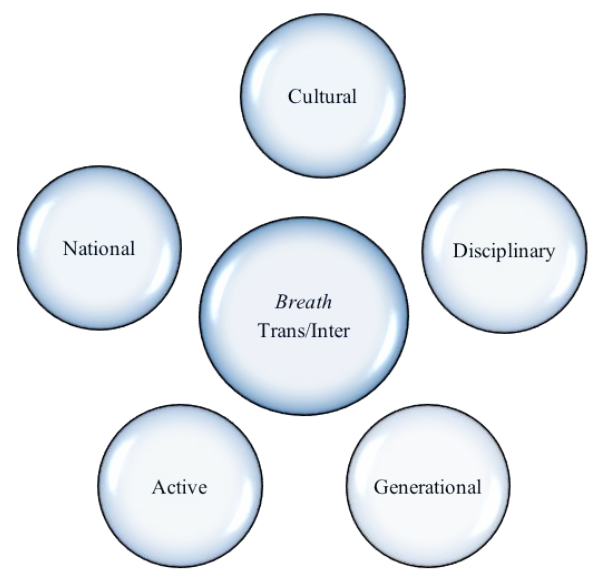

\section{Conclusions}

Under the multiplicity of social approaches to migration nowadays in Europe, and the risk to misunderstand the significance to live in a pacific and respectful society, it becomes necessary to develop pioneering ways to celebrate the diversity of European nowadays cultural contexts, creating paths for cultural encounters, enhancing the diversity as a ship flag in the understanding of the current social environments. Here, music, sound and video art could be a touchstone. As an example, Breath installation constitutes an international platform of interaction between different constituents of society, an accessible scenario to link academia and people, a stage for social transformation that can incident, in an original and attractive manner, towards the socialization of nowadays European cultural contexts by shedding light on human emotions. Finally, Breath aims to be a seed for future communication/dissemination strategies on transdisciplinary approaches and a solid contribution to recognition processes within migration contexts. 


\section{References}

BAILY, J. \& COLLYER, M. (2006). Introduction: Music and Migration. Journal of Ethnic and Migration Studies, 32 (2), 167-182.

BANK, R. (2014). Forced Migration. In Fiddian-Qasmiyeh, Elena; Loescher, Gil; LoNG, K. \& SIGONA, N.. The Oxford Handbook of Refugee and Forced Migration Studies. Oxfrod, Oxford University Press.

Bogdanovic, N. (2016). Artistic Excellence as a Result of Migration. In Sounds in Europe: Music and Migration. European Music Council, 11, 4-6.

Bohlman, P. (2003). Music and cultures: historiographies of disjuncture. In Clayton, Martin et al. (eds.) The cultural study of music: a critical introduction. New York: Routledge.

Bohlman, P. (2011). When Migration Ends, When Music Ceases. In Music and Arts in Action, 3 (3), 148-166.

Cook, N. (2003). Music as performance. In Clayton, Martin et al. (eds.) The cultural study of music: a critical introduction. New York: Routledge.

FeLD, S. \& BRENNEIS, D. (2004). Doing anthropology in sound. American Ethnologist, XXXI (4): 461 474.

HAHONOU, E. K. (2019). Emotions as method: Obtrusiveness and participant observation in public bureaucracies. Critique of Anthropology. 39 (2). 188-204.

KasinitZ, P. \& M. Martiniello (2019). Music, migration and the city. Ethnic and Racial Studies, 42:6, 857-864.

KIWAN, N. \& MeINHOF, U. (2011). Music and Migration: A Transnational Approach. Music and Arts in Action, 3 (3), 3-20.

KNOTT \& MCLOUgLIN (2010). Diasporas, concepts intersections, identities. London, Zed Books.

Mc Auliffe, M. (2019), World Migration Report 2020, Geneva, International Organization for Migration.

NetTL, B. (2004). Introduction: studying musics of the world's cultures. In Nettl, Bruno et al. Excursions in world music. New Jersey: Pearson Prentice Hall.

NIESSEN, J. (2000). Diversity and cohesion: new challenges for the integration of immigrants and minorities. Berlin: Council of Europe Publishing.

OchoA, A. M. (2003). Músicas locales en tiempos de globalización. Buenos Aires: Norma.

PALACIOS, F. (2018). Culturas intangibles en Movimiento: la música tradicional afroesmeraldeña. Quito: Abya Yala.

RoBINSON, R. (2016). Music Festivals and the politics of participation, London, Routledge.

SCHNeIDeR, S. \& HeAth, A. F. (2016). Uncovering ethnic and cultural diversity in Europe: A new classification of ethnic and cultural groups. In: Ethnicity and ancestry. 3rd International ESS Conference. Lausanne, Switzerland 
Sechehaye, H. and Martiniello, M. (2019). Refugees for Refugees: Musicians between Confinement and Perspectives, Arts, 8 (14).

SORCE, K. M, \& BARWICK, L. (2012). Thoughts on Music and Migration. In BARWICK, L. \& SORCE KelleR, M. (Eds.), Italy in Australia's Musical Landscape (225-231). Melbourne: Lyrebird.

VIGH, H. E. (2018). Lives opposed: perceptivity and tacticality in conflict and crime. Social Anthropology - Anthropologie Sociale, 26(4), 487-501. 